\title{
UNDERSTANDING AND EVALUATING PERSONAL LETTER WRITING: A SYSTEMIC FUNCTIONAL LINGUISTICS ANALYSIS OF STUDENT TEXTS IN ONE OF SENIOR HIGH SCHOOL IN INDONESIA
}

\author{
Alfira Veronica Mangana \\ Department of English Education, School of Postgraduate Studies, \\ Universitas Pendidikan Indonesia, Indonesia \\ E-mail: alfiraveronicamangana@upi.edu \\ Eri Kurniawan \\ Department of English Education, School of Postgraduate Studies, \\ Universitas Pendidikan Indonesia, Indonesia \\ E-mail: eri_kurniawan@upi.edu
}

\begin{abstract}
APA Citation: Mangana, A. V., \& Kurniawan, E. (2020). Understanding and evaluating personal letter writing: A systemic functional linguistics analysis of student texts in one of senior high school in Indonesia. Indonesian EFL Journal, 6(2), 165-174. doi: 10.25134/ieflj.v6i2.3385.
\end{abstract}

Received: 12-12-2019

Accepted: 21-04-2020

Published: 01-07-2020

\begin{abstract}
Based on 2013 Curriculum, Personal Letter can be considered as one of the challenging text types that should be mastered by the students. This might be the reason why the text is taught in Senior High School Level. Therefore, it is crucial for the teachers to expand their knowledge regarding this type of genre to overcome students' problems faced during writing personal letter. This study is aimed to analyse student's Personal Letter text based on three metafunctions in SFL perspective. It is expected that by identifying students' problems, teachers can decide and design appropriate pedagogical plan. The data of this descriptive qualitative study were analysed by using three metafunctions in Systemic Functional Linguistics (SFL). The result of the study reveals that the student's major problems in producing Personal Letter text are the use of subject and verb tense (interpersonal metafunctions), the generic structure of the text, the use of conjunctions, the grammatical errors, and L1 interference.
\end{abstract}

Keywords: personal letter; systemic functional linguistics; metafunction; discovery learning strategy.

\section{INTRODUCTION}

In July 2013, the education system in Indonesia establishes a new curriculum that is 2013 Curriculum. There are many factors underlying the establishment of the 2013 Curriculum including in the Law No. 20: 2003 that concerns the purpose of national education to develop students' potentials to become persons of faith and fear of God, noble, healthy, knowledgeable, capable, creative, independent, and become citizens of a democratic and accountable. In addition, in order to realize the ideals of educating the nation that in line with the vision and mission of national education, Ministry of National Education (Renstra Kemdiknas, 2010-2014) had a vision in 2025 to produce intelligent and competitive Indonesians (Perfect human/Plenary). According Mulyasa (2013: 19) argues that "Smart Indonesians is comprehensive intelligent beings, that spiritual intelligent, emotionally intelligent, socially intelligent, smart intellectual, and kinesthetic intelligent".
The term socially intelligent means having competence in communication not only in spoken but also in written, or it is commonly known as social skills (Permendiknas No. 22, 2006; Emilia et al., 2008). Thus, several years before 2013 Curriculum is nationally applied in EFL classroom, Genre-Based Approach has already been adopted and implemented by Indonesian Government to improve students' ability in communication (Emilia et al., 2008) and is still used in nowadays teaching process (Potradinata, 2018). According to Suherdi (2013), there many kinds of genres like monologues, interpersonal and transactional conversation, and essays of particular genres such as descriptive text, procedural text, narrative text, personal letter text, and other similar things which are claimed as kinds of text. Nevertheless, unlike other genres, personal letter text, as the oldest and most basic form of written communication (Barton, \& Hall, 1999; Ivask, 1990, cited in Mortensen, 2003), provides us an option for linguistic or social interaction that fulfils the demands that are not 
Understanding and evaluating personal letter writing: A systemic functional linguistics analysis of student texts in one of senior high school in Indonesia

provided by spoken communication. However, to learn English texts as a foreign language, there may be no doubt that Indonesian student might experience difficulty in terms of structure and context (Sayukti \& Kurniawan, 2018). In other words, this condition is also considered as interlanguage which describes the language learner develops a linguistic system of his native language (L1) in mastering the target language (L2) (Selinker, 1972). In brief, it is a condition when L1 influences the L2 linguistic system and causes an error in representing a proper target language. Thus, it is significant to address this issue in order to provide educational resources for teaching in teaching writing.

There have been several studies of Systemic Functional Linguistics (SFL) perspectives on students' writing analysis in EFL setting. Nurohmah (2013) studied writings of the eighth semester students of English Department in one university in Bandung, Indonesia. Using SFL analysis, majority of students cannot differentiate between the use of simple present, past tense, irregular, regular verb, and prepositional phrase (Nurohmah, 2013). In another case study conducted in junior high school in Indramayu, Indonesia, most of the students still made mistakes in identifying past verb in writing recount text (Yulianawati, 2015). Noviyanti (2015) reveals that mostly students used the reiteration pattern by repeating the same element as a theme and employed the zigzag pattern to make a sense of cumulative development of a text. Another study identified that transliteration is also the most common interference used by the students, followed by omission errors, spelling errors, the incorrect pronoun used and incorrect word use (Owu-Ewie \& Lomotey, 2016).

As previous studies mostly concern on the analysis of recount text based on the grammatical error, this study intends to analyze students' selfcomposed Personal Letter text in SFL perspectives and its implication toward the meaning of the text. As based on Senior High School Syllabus of 2013 Curriculum, Personal Letter itself is one of text genres that should be taught to the students. However, personal letter seems to be more challenging, commonly addressed to intimates, since it needs an absence of knowledge by both the reader and writer to be shared (Crane, 2016). Writing personal letter in a foreign language is also connected to the needs to present an identifiable set of procedures to fulfil the criteria on tasks like discussing personal issues, congratulating, inviting, greeting, and so forth that are culturally bind. Moreover, personal letter requires a different process in terms of constructing ideas, conducting a uni-direction argument, or encoding information and presentation (Khotib, 2001).

Therefore, it is essential for the teachers to expand their knowledge regarding text genre, here specifically personal letter text, to overcome students' problems faced during writing personal letter. One way to help the teachers master and tackle the said problems is by investigating the students' personal letter text through Systemic Functional Linguistic (SFL) framework that is believed can provide a solution to explore a text comprehensively. The analysis will contain 3 types of language Metafunctions promoted by Halliday (2014) and Eggins (2004) namely Interpersonal meaning, Experiential meaning, and Textual meaning. Furthermore, the features of the text written by the student will be shown and then compared to the ideal one. As a result from the problems found, a best method can probably be considered to be implemented by the teacher when teaching this kind of genre.

\section{METHOD}

The present study intended to explore how student's personal letter text writing is analysed through the perspectives of SFL. Concerning to the phenomenon, the researcher utilized a qualitative case study approach. A qualitative case study design is useful to address explanatory questions to a social phenomenon (Hamied, 2017). The fact that case study is closely related to its generalizability, Punch and Oancea (2014) believe that there are some types of case where generalization is not the main purpose of the study. This study, moreover, described and reported the type of grammatical cohesion occur in analytical personal letter texts written by students systematically, factually and accurately based on the data of the research.

The data of this research was collected from a student's work of personal letter text during the English class. The writing was deliberately chosen from a student at the Eleventh grade of a Senior High School in Bandung, West Java, Indonesia during the even semester of academic year 2019/2020. The writing was chosen based on the consideration that the writing represent the problems faced in writing class.

This study used triangulation for collecting the data in order to deal with the validity of the study. Thus, the instruments of the research were students' corpus, observation, semi-structured 
interview, and class' documents like lesson plan, modules, and syllabus.

Based on the research instruments above, at first, the corpus of students was collected from the teaching process by the teacher. Then the semi-structured interview was conducted with the English teacher and the classroom observation was applied to find out the methods implemented by the teacher in teaching Personal Letter and know more about the problems faced by the students in writing the text. Eventually, modules and lesson plan of the teacher were checked to see the correlation with the text written by the students.

The content analysis approach was used to analyze writing errors of students in the personal letter text. The data was collected through the process of observing, analyzing and interpreting. At first, a semi-structured interview was done with the English teacher. The questions of the interview was carried out based on the problems faced by the students in learning personal letter writing and the teacher in teaching writing. Furthermore, the researcher was analyzed and diagnosed the meta-function in the samples to find out its appropriateness with the theories underlying personal letter text. As a result, a comprehensive analysis was done based on the social function, schematic structures, and language features from SFL perspectives namely interpersonal meta-function, experiential metafunction, and textual meta-function.

In addition, the corpus was analyzed in terms of the letter's schematic structure, i.e., the preferred structural properties consisting of various obligatory and optional 'stages' (Hasan, 1996) that relate to specific communicative acts and collectively realize a text's larger communicative purpose. Understanding a genre's structure allows one to track linguistic patterns and strategies that language users deploy as they move texts from a starting to an end point. In this way, genre provides a contextual framework to understand how and why particular language appears where it does in a text.

Additional analyses of the dominant lexicogrammatical resources appearing in the letters' unfolding stages were conducted to identify the different linguistic strategies that writers draw on in personal letter writing. Given the key role that affects plays in letters, the primary focus of this part of the analysis was evaluative language, i.e., language used to convey emotions, attitudes, and stances. Here, SFL's functionally-oriented framework of Appraisal (Martin \& White, 2005) was used to explore evaluative meanings in the texts (i.e., the positive-negative nature of the evaluations, and its degree of explicitness or implicitness) and relate the most common and effective lexico-grammatical patterns to the register variables of field, tenor, and mode. In SFL, the construct of 'register' refers to three main meaning types that exist at clausal and discourse levels: Field is concerned with the semantic domain of propositional content; tenor refers to participants and their relationship to each other; and mode considers the contribution that text makes in presenting information (Halliday \& Matthiessen, 2004).

\section{RESULTS and discussion}

The analysis of a student's writing in SFL context

\section{Interpersonal meta-function}

Interpersonal meta-function of a text can be somehow challenging for the foreign learners who learn the level of formality of certain genre since it marks the relationship between the writer and reader and how the writer put his/herself in that writing. It can be investigated through Mood and Modality System. Mood can be analyzed from how subject and finite are organized in a clause in a text, while Modality System can be seen by looking at how various devices, namely Modal Finite, Mood Adjunct, and grammatical metaphor are utilized to make meaning.

Regarding Mood, advanced writers of personal letter text typically use statements as the speech functions in order to give information as commodity to the readers. This question statement is seen by declarative mood generally constructed in (but not limited to) the structure Subject ${ }^{\wedge}$ Finite (Thompson, 2014). By looking into the text analyzed, 7 out of 12 clauses are written in declarative mood. Clauses are began with subject, and then finite comes after. With one or some adjuncts precede them in some cases. From The use of declarative mood eases the writer to express the information to the reader, which in this case most of his statements are about the topic. Nonetheless, some of the clauses are not constructed well. Some of clauses miss one or some elements in Mood.

The following are the examples.

Clause 3: you ( ) fine

Clause 4: How ( ) for plan next week,

Clause 7: if you there activities.

Clause 8: Bay the way I will coming in your home next week, $O$ 'clock 02:00 Pm. 
Understanding and evaluating personal letter writing: A systemic functional linguistics analysis of student texts in one of senior high school in Indonesia

From the examples above, the student probably finds difficulty in making proper sentences. Some clauses do not contain Finite and Predicator, whereas some others use incorrect predicator (as in clause 4 and 8 ) and Subject (like in clause 4). Then in term of preposition, she is still confused to differentiate between "in" and "to" in term of its usage, resulting on the use of "in" rather than 'to' that refers to your home (in clause 8). Furthermore, it can be seen that the student missed to use punctuations like (?) in Clause 3, and (,) in Clause 8, and wrote misspelled words.

In term of Finiteness and tenses, most of statements are stated in the Present time, indicating that the writer wants to express single modality of factuality or certainty (Kress 1985; Eggins, 1994 in Emilia, 2014), while one of them is Future time like will as a Median Modality that shows possible willingness to do in the future (Emilia, 2014). Moreover, it cannot be found a description of some acts taken place in the past, and thus the student does not use any past tense form in her clause.

Regarding the relationship between the writer and the reader in this writing is relatively close, since the writer uses first person pronoun "I" in the second clause of her text to show her position in the topic, and she is likely to use second person

pronoun "you" to address the reader more frequent. This way of establishing interaction of interlocutors results in showing higher degree of intimates between the writer and the reader. The way of using first or second person pronoun is permitted since it is a personal letter that aims to be sent to the relatives or friends who are closed to the writers.

About the Modality, some clauses use some instances of modality which are used to reflect possibility, as in Bay the way I will coming in your home next week, O'clock 02:00 Pm. This shows the student's capacity to express writer attitude toward what she is saying. The student has succeeded to use modality in her writing to show her willingness (Kress, 1985 in Emilia, 2014).

\section{Experiental metafunction}

In Personal letter text, Experiental metafunction represents the feelings, thoughts, and actions that are associated with the writer and the reader, and their respective situation on the daily discourse of the participants (Crane, 2016). Due to understanding how experiential meaning is made by the learners, teachers can use transitivity analysis to analyze how participants, processes, and circumstance of a clause are organized in particular ways.

\begin{tabular}{ll}
\hline Clause 8 & Bay the way II will coming (Pr: Material) in your house.... \\
Clause 10 & You stay (Pr: Material.) \\
Clause 11 & And (you) wait for my coming $(\operatorname{Pr}:$ Material.)
\end{tabular}

Based on the transitivity analysis of the sample text, five types of process appear: Possession process, Affection Proccess, Mental process, Verbal process, Material Process, and Relational process. The student starts his writing using mental process, as in How are you?. This opening reveals how the writer wants to know the condition of the readers. The use of mental process in the clause constructs feeling and sense in line with the function of the clause- to open the topic. For the next clauses, the writer still uses mental process to show her affection to the reader. However, the most frequent type of process used by the writer is Material process. Typically, the sample regularly uses Material process to express the notion that some entity physically does something. The examples of how the student constructs a clause can be seen as follows:

The use of Material process makes the student able to pass information, which is related to the topic, to the reader. However two of those clauses seem to order the readers to do something based on what the writes ask her to do.

Moving to participant roles, the first participant role, as mentioned previously, is that of Senser assigned to "you" and "I". The presence of Senser may constitute an attempt from the writer to emphasize on personal feeling and willingness toward the topic. Despite introducing the main topic, "School Holiday" as the participant of the clause, the writer directly presents her personal intimates by using second person pronoun to shows the writer as the Participant of the clause. Since other clauses have a Material (goal) process and a Mental Process, the roles of Senser appear frequently.

Other interesting problem faced by the student can be seen when she tries to construct a clause by using possession process like the example below: 


\begin{tabular}{|c|c|c|c|c|c|}
\hline \multicolumn{6}{|l|}{ Clause 7} \\
\hline & If & you & \multicolumn{2}{|c|}{ there } & activities. \\
\hline \multirow[t]{2}{*}{ Interpersonal } & $\begin{array}{c}\text { Conjunctive } \\
\text { Adjunct }\end{array}$ & Subject & Finite & Predicator & Complement \\
\hline & \multicolumn{3}{|c|}{ MOOD } & \multicolumn{2}{|c|}{ RESIDUE } \\
\hline Experiential & & Possessor & \multicolumn{2}{|c|}{ Pr: Possession } & Possessed \\
\hline \multirow[t]{2}{*}{ Textual } & Textual & Topical & \multirow{2}{*}{\multicolumn{3}{|c|}{ Rheme }} \\
\hline & & & & & \\
\hline
\end{tabular}

From the example above, it can be investigated that Instead of using the proper predicator to show possession like 'have', she uses 'there' which is known to have the same meaning in the student's first language, Indonesian. It can be assumed that the student is disturbed with the cultural issues in using language.

\section{Textual metafunction}

Textual metafunction considers how the communication is channeled in the text. Moreover, it tells where a clause in a text comes from, and where it goes to (Gerot \& Wignell, 1995). Textual meaning of a text can be analyzed by using Theme system analysis (or ThemeRheme connection).

The sample letter is about school holiday, but in the whole analyzed text cannot be found any word or clause that presents the school holiday as the theme of the letter assigned. In the text analyzed, the first theme mentioned in the beginning of the text is not about the condition of the reader, yet it is commonly used to open the topic in a personal letter text. Thus, the sample text starts by using personal pronoun "you" as the rheme, that then becomes the topical theme in the next 2 clause. Nonetheless, overall, the student likely starts with Textual Theme, and the absence of actual theme can be seen as follows.

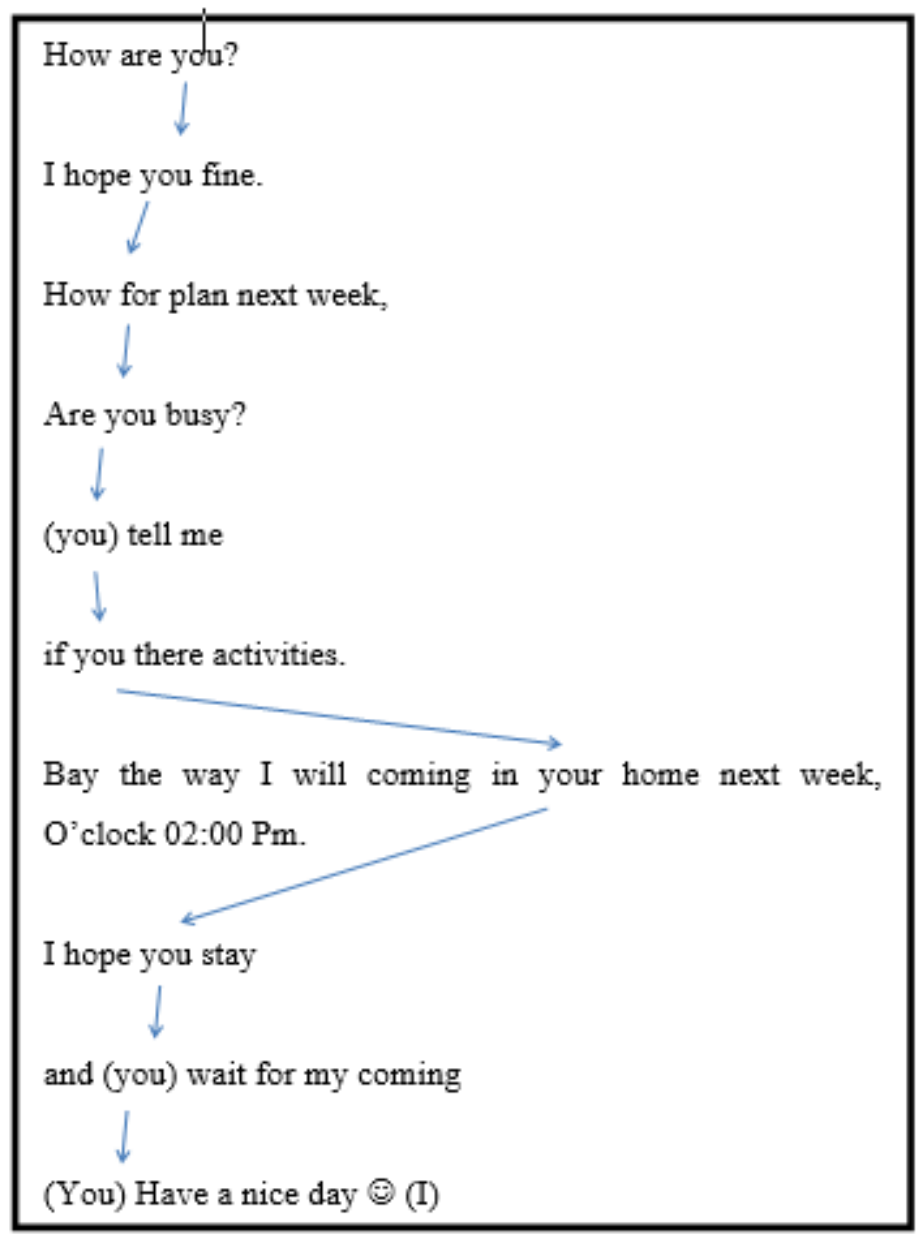


Understanding and evaluating personal letter writing: A systemic functional linguistics analysis of student texts in one of senior high school in Indonesia

Overall, it can be seen that the theme of the writer means in her letter is to ask and give information about her willingness to come to the reader's house at a particular time stated by the writer.
Meanwhile, the sample text successfully uses Textual Theme realized in conjunctions (both coordinating conjunctions and subordinating conjunctions). The use of conjunctions as Textual Themes gives texture to the text. Examples of Textual Themes in the text are:

\begin{tabular}{|c|c|c|c|}
\hline \multicolumn{4}{|c|}{ Clause 6} \\
\hline & & Tell & $\mathrm{Me}$ \\
\hline Interpersonal & Finite & Predicator & Complement \\
\hline Textual & & al Theme & Rheme \\
\hline
\end{tabular}

\begin{tabular}{|c|c|c|c|c|c|}
\hline \multirow[t]{2}{*}{ Clause 7} & & & & & \\
\hline & If & You & \multicolumn{2}{|c|}{ There } & activities. \\
\hline Interpersonal & $\begin{array}{c}\text { Conjunctive } \\
\text { Adjunct }\end{array}$ & Subject & Finite & Predicator & Complement \\
\hline \multirow[t]{2}{*}{ Textual } & Textual & Topical & \multirow{2}{*}{\multicolumn{3}{|c|}{ Rheme }} \\
\hline & Ther & & & & \\
\hline
\end{tabular}

The use of Textual Themes in the text shows the writer's capacity to construct clause complexes in the text that becomes one of characteristics of written text (Emilia, 2014).
To organize the text so that the clauses are coherent one another, the sample text uses the Theme Reiteration. In the Theme Reiteration, an element is only reiterated by the writer to keep a text cohesive and focused. Examples of it is:

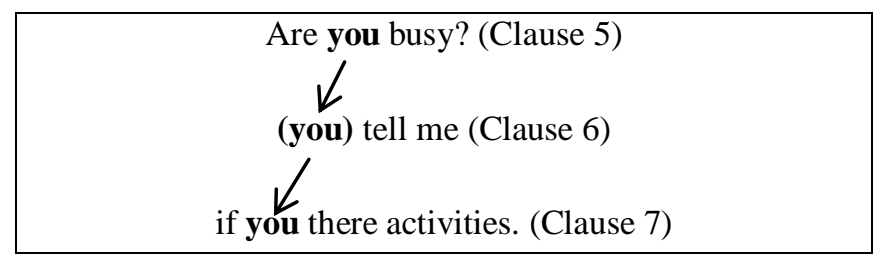

\section{The theme reiteration}

From the example, the student succeeds to construct the Thematic Reiteration as thematic progression in her writing; repetition of elements (which in this case is you) is done to keep the text cohesive and focused. However, it cannot be bound the Zigzag pattern of this thematic scheme, the text does not appropriately follow the pattern. On the other words, despite using Rheme of a clause as Theme in next clause, the writer comes with a new Theme which is not mentioned in the previous clause. This issue also usually occurs in the text. It means that the student is likely to face problem in maintaining thematic progression particularly the Zigzag Pattern.

\section{The analysis of text features Social function}

In general, the social function of analytical personal letter text is to make sense of events through the imagined lived experiences of two human beings (Crane, 2016). This purpose can be accomplished by giving appropriate information based on the theme in the body of the letter by means that readers can understand the main the topic wanted to convey by the writer as an important thing to be concerned.

Thus, it can be concluded that the writer is failed to construct a text which aims to talk about the school holiday, yet the reader seems to understand the information of the writer regarding her intention to come to the reader's house. It is probably understood by the clause: I will coming to your house next week, wait for my coming. Those statements are delivered in the form of 
declarative mood and contain modality to share information in certain degree of probability/certainty.

\section{Generic structure}

Based on the 2013 Curriculum, Personal letter text commonly consists of eight parts, namely date, address, salutation and name, introduction, body, closure, complimentary close, and signature. Regarding the date and address, those reveal when and where the letter is written. The second stages are salutation and name that show greeting and the name of the addressee like "Dear" for the intimate ones. Then, in introduction, the writer presents the opening of the letter, sometimes like 'How are you?' to show the personal affection to the reader. Next the main stage of the latter is the body that contains the actual purpose of the writer in writing the latter.
The 3 last parts are closure, complimentary close, and signature. In those stages, the writer initially begins a sentence that indicates that the letter is going to end, and it is then closed by some specific words that can depict the relation between the participants such as Best regards, your best friend, sincerely yours, love, and so forth, that latter will be signed using the name or signature of the sender.

It can be analyzed from the table above that the text does not written in a proper structure since the writer does not put the date, address, and the complimentary close. A more professional letter presents appropriate address forms and conventionalized communicative acts like salutation that reveal a fixed level of formality of both interlocutors (Crane, 2016). The following is analysis of generic structure of the sample text:

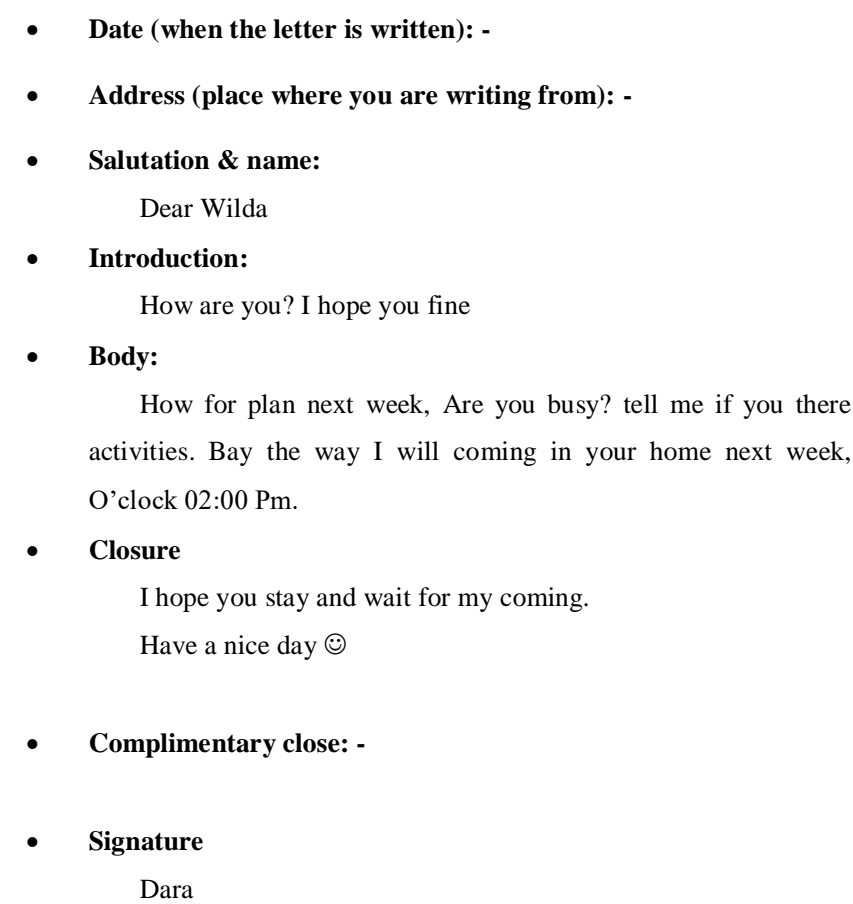

\section{Linguistics features}

According to Gerot \& Wignell (1995), there are several important lexicogrammatical features of analytical, like the use of simple tense, the use of relational process, the use of internal conjunctions, and the use of reasoning through causal conjunction and nominalization. The first two features appear in the sample texts. The simple tense is used in the text to show single modality of factuality, while the relational process is only used once to assign quality. Unfortunately, internal conjunctions and causal conjunction are poorly implemented in the text, resulting in weak connections between clauses. Nominalization also becomes problem for the students as there is no nominalization found in the text.

\section{CONCLUSION}

Based on the Systemic Functional Linguistics analysis above, there are some obstacles encountered by the students in writing a personal letter text. Interpersonally, the students find it is hard when dealing with Finite and predicators. In Experiential metafunction, the problem is in form of word choices showing a process of possession. While textually, the challenges comprise the 
Understanding and evaluating personal letter writing: A systemic functional linguistics analysis of student texts in one of senior high school in Indonesia

proper organization of Theme-Rheme in thematic progression. Furthermore, the crucial one is the student misses some parts of the general structure as the basic elements of every kind of genre text. Therefore, the failures may come from some weakness that should be fixed hand by hand by both teacher and student and need to be solved so that the students can construct text better and more appropriate with its function in the culture.

By implementing SFL GP approach, the students are likely to have a better assistance in building the text knowledge and also in creating the text independently. Moreover, by teaching the text in the perspective of SFL, teachers are expected to be more aware of what to emphasize in the learning practices and how to approach a text. Nonetheles, SFL GP literally may need more time since it is developed to deal with a text as a mean of social communication rather than a mere grammatical structure.

On the other hand, regardless the challenges and the limitations of the approach, SFL GP may become a promising approach if it is carried out systematically and done optimally.

\section{REFERENCES}

Ali, A. \& Tanzili. (2006). Pedoman lengkap mnulis surat. Jakarta: Kawan Pustaka

Al-Khatib, A., Mahmud. (2001). The pragmatics of letter-writing. World Englishes, 20(2), 179-200.

Anderson, M., \& Anderson, K. (2003). Text Types in English 1. Australia: Macmillan. Barton, D., \& Hall, N. (2000). Introduction. In D. Barton \& N. Hall (Eds.), Letter writing as a social practice (pp. 1-14). Philadelphia: John Benjamins.

Bloor, M. (1996). Academic writing in computer science. In E. Ventola \& A. Mauranen (Eds.), Academic writing: intercultural and textual issues (pp. 59-87). Philadelphia: John Benjamins Publishing Co.

Bloor, T., \& Bloor, M. (2004). The functional analysis of English: A Hallidayan approach (2nd ed.). London: Arnold.

Brown, H. (1935). The great American novel. American Literature: A Journal of Literary History, Criticism, and Bibliography, 7(1), 1-14.

Byram, K. (2011). Using the concept of perspective to integrate cultural, communicative, and formfocused language instruction. Foreign Language Annals, 44(3), 525-543.

Byrnes, H., Maxim, H. H., \& Norris, J. M. (2010). Realizing advanced foreign language writing development in collegiate education: Curricular design, pedagogy, assessment. Modern Language Journal, 94 (MLJ Monograph Series).

Connor, U., \& Mayberry, S. (1996). Learning discipline-specific academic writing: a case study of a Finnish graduate student in the United States.
In E. Ventola \& A. Mauranen (Eds.), Academic writing: Intercultural and textual issues (pp. 231253). Philadelphia: John Benjamins Publishing Co.

Crane, C. (2016). Understanding and evaluating L2 personal letter writing: A systemic functional linguistics analysis of student texts in German university of texas.

Cresswell, J. W. (2014). Research Design: Qualitative, Quantitative and Mixed Methods Approaches (4th ed.). SAGE Publications.

Dirgeyasa, I. W. (2016). Genre-Based Approach: What and How to Teach and to Learn Writing. English Language Teaching, 9(9), 45-51.

Eggins, S. (2004). An Introduction to Systemic Functional Linguistics. NY: Continuum. Ellis, J. (1987). The logical and textual metafunctions. In M.A.K. Halliday \& R. Fawcett (Eds.), New developments in systemic linguistic, Volume 1: Theory and Description (pp. 107- 129). New York: Francis Pinter.

Emilia, E. (2014). Introducing Functional. Grammar.Bandung: Pustaka Jaya.

Faigley, L. (2006). The brief Penguin handbook: Custom edition for the department of English at Marshall University (2nd ed.). New York: Pearson Custom Publishing.

Fitzmaurice, S. M. (2002). The familiar letter in Early Modern English. Philadelphia: John Benjamins.

Fries, P. (1981). On the status of theme: Arguments from discourse. Forum Linguisticum, 6(1), 1- 38.

Fries, P. (1995). Theme, methods of development, and texts. In R. Hasan \& P. Fries (Eds.), On subject and theme: A discourse functional perspective (pp. 317-359). Philadelphia: John Benjamins Publishing Co.

Gee, J. P. (1998). What is literacy? In V. Zamel \& R. Spack (Eds.), Negotiating academic literacies: Teaching and learning across languages and cultures (pp. 51-59). Mahwah, NJ: Lawrence Erlbaum.

Gerot, L., \& Wignell, P. (1995). Making Sense of Functional Grammar: An Introductory Workbook. Australia: Gerd Stabler.

Gregory, M. (1987). Meta-functions: aspects of their development, status and use in systemic linguistics. In M. A. K. Halliday \& R. Fawcett (Eds.), New developments in systemic linguistic, Volume 1: Theory and Description (pp. 94-106). New York: Francis Pinter.

Hakim, M., Riswanto, R., \& Rafiska, L. (2016). The Use of genrebased approach in the context of English foreign language curriculum development at Islamic schools in Indonesia people. International Journal of Social Sciences, 2(1), 1530-1539.

Halliday, M.A.K. and Matthiessen, C.M.I.M. (2014) Halliday's introduction to functional grammar (4th edition). London: Routledge. 
Hamied, F. (2015). ELT Intricacies within the Indonesian language policy. English for ASEAN Integration: policies and practices in the region. Bandar Sri Begawan: IELTS.

Hamied, F. (2017). Research methods: A guide for first-time researchers. Bandung: UPI Press.

Harmer, J. (2007). The practice of English language teaching. Malaysia: Pearson Education Limited.

Hasan, R. (1996). The nursery tale as a genre. In C. Cloran, D. Butt \& G. Williams (Eds.), Ways of saying: Ways of meaning. Selected papers of Ruqaiya Hasan (pp. 51-73). New York: Cassell.

Hidayati, E., Sukam, D. \& Antoni, R. (2015). Improving students' writing skill in recount text by using personal letter at eight grade of SMP tiga hati kepenuhan hulu. English Study Program, Faculty of Teacher Training and Education, University of Pasir Pengaraian.

Horn, B. (2011). The future is now: Preparing a new generation of CBI teachers. English Teaching Forum, 49(3), 2-9.

Hyland, K. (2004). Genre and second language writing. Ann Arbor, MI: University of Michigan Press.

Indonesian Ministry of Education and Culture. (2016). Buku saku gerakan literasi. Jakarta: Indonesian Ministry of Education and Culture.

Kearney, E. (2012). Perspective-taking and meaningmaking through engagement with cultural narratives: Bringing history to life in a foreign language classroom. L2 Journal, 4(1), 58-82.

Kementrian Pendidikan dan Kebudayaan. Modul pelatihan implementasi kurikulum 2013. Jakarta: Badan Pengembangan Sumberdaya Manusia Pendidikan dan Kebudayaan dan Penjamin Mutu Pendidikan Kementrian Pendidikan dan Kebudayaan.

Kern, R. (2000). Literacy and language teaching. New York: Oxford University.

Kirkwood, R. (2006). Introductory letter. In The brief Penguin handbook: Custom edition for the department of English at Marshall University (2nd ed.). New York: Pearson Custom.

Knapp, P., \& Watkins, M. (2005). Genre, text, grammar: Technologies for teaching and assessing writing. Sidney: UNSW Press.

Knutson, E. (2012). Teaching difficult topics: The example of the Algerian War. L2 Journal, 4(1), 83-101.

Maria N. \& Katerina T. Frantzi. (2017). Genre identification based on SFL principles: The representation of text types and genres in English language teaching material. department of mediterranean studies, Greece. Corpus Pragmatics, 1:373-392

Martin, J. R. (1991). Nominalization in science and humanities: Distilling knowledge and scaffolding text. In E. Ventola (Ed.), Functional and systemic linguistics (pp. 307-337), Berlin: Mouton de Gruyter.

Martin, J. R., \& Rose, D. (2003). Working with discourse: Meaning beyond the clause. London: Continuum.

Martin, J. R., \& Rose, D. (2008). Genre relations: Mapping culture. London: Equinox. Melissourgo,

Mortensen, L. (2005). Written discourse and acquired brain impairment: Evaluation of structural and semantic features of personal letters from a Systemic Functional Linguistic perspective. Clinical Linguistics \& Phonetics 19, 227-247.

Mulyasa. (2013). Pengembangan dan implementasi kurikulum 2013. Bandung: Remaja Rosdakarya.

Nafisah, N., \& Kurniawan,E. (2007). Writing English Press

Noviyanti (2015). Thematic progression in students' recount texts. E-Journal of English and Education, 3(2), 65-76.

Nurlaelawati, I., \& Novianti, N. (2017). The practice of genre-based pedagogy in Indonesian schools: a case of pre-service teachers in Bandung, West Java province. Indonesian Journal of Applied Linguistics, 7(1), 160-166.

Nurohmah, I. (2013). An analysis of students' recount text by using systemic functional grammar. Passage, 1(2), 89-98.

Paesani, K., Allen, H. W., \& Dupuy, B. (2016). A multiliteracies framework for collegiate foreign language teaching. Upper Saddle River, NJ: Pearson.

Piruat, J., \& Lopez-Barneo, J. (2005). Oxygen tension regulates mitochondrial DNA-encoded complex I gene expression. The Journal of Biological Chemistry, 280(52), 42676-42684.

Taguchi,N. (2012). Context, individual differences and pragmatic competence. New York/Bristol: Multilingual Matters.

Tardy, C. M., \& Swales, J. M. (2014). Genre analysis. In K. P. Schneider \& A. Barron (Eds.), Pragmatics of discourse (pp. 165-187). Berlin: Mouton De Gruyter.

Thompson, G. (2004). Introduction to functional grammar ( $2^{\text {nd }}$ edition). London: Arnold Publishers. 
Alfira Veronica Mangana \& Eri Kurniawan

Understanding and evaluating personal letter writing: A systemic functional linguistics analysis of student texts in one of senior high school in Indonesia 